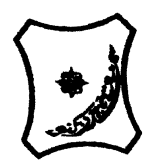

Bayero Journal of Pure and Applied Sciences, 10(1): 468 - 476

ISSN $2006-6996$

\title{
SYNTHESIS, CHARACTERIZATION AND ANTIMICROBIAL STUDIES OF RU(II) COMPLEXES WITH SCHIFF BASE CO-LIGAND DERIVED FROM 5,6-DIAMINO-1,10- PHENANTHROLINE AND BENZENE-1,4-DICARBALDEHYDE
}

\author{
Sadi, A. H.*, Idris, M. $\mathrm{I}^{2}$ and Bashir, S. S. ${ }^{3}$ \\ "Department of Pure and Industrial Chemistry, Bayero University, Kano, Nigeria. \\ ${ }^{2}$ Department of Chemistry, Nigeria Police Academy-Wudil, Kano, Nigeria. \\ ${ }^{3}$ Department of Chemistry, Rabiu Musa Kwankwaso College of Advance and Remedial Studies, \\ T/wadaDankadai, Kano, Nigeria. \\ Email: sahassan197@gmail.com Phone number: +2348038556812
}

\section{ABSTRACT}

Two novel biologically active Ru(II) complexes with coordinating Schiff base were synthesized and characterized by elemental analysis, FT-IR, UV-visible and mass spectral analyses. On the basis of analytical and spectral data, octahedral geometry was assigned to both complexes and structural formulae have been tentatively proposed. The complexes were found to be coloured and readily dissolved in DMSO, DMF, MeOH, EtOH and $\mathrm{CH}_{3} \mathrm{CN}$. Molar conductivity measurement in dimethyl sulphoxide (DMSO) solutions shows the electrolytic nature of both complexes in 1:2 ratios suggesting the presence of chloride ions in the outer sphere of the complexes. The Schiff base and metal complexes were screened for their antibacterial and antifungal activities.

Keywords: Metal Complexes, Schiff base, Outer sphere, antibacterial and antifungal activities

\section{INTRODUCTION}

Schiff bases

Schiff base compounds are condensation products of primary amines and carbonyl compounds (aldehydes and ketones) and were discovered by a German chemist (Nobel Prize winner) Hugo Schiff in 1864 (Ashraf et al,. 2011, Brodowska et al,. 2014).

Schiff base possess functional group containing carbon-nitrogen double bond with the nitrogen atom linked to an aryl or alkyl group, with the exception of hydrogen (Kostova and Sasa, 2013).

Schiff bases in a broad sense are compounds containing azomethine group $(>\mathrm{C}=\mathrm{N})$ and have the general structure $R^{1} R^{2} C=N R^{3}$, where $R^{1}, R^{2}$ and $\mathrm{R}^{3}$ are aryl, alkyl, cycloalkyl or heterocyclic groups that are of different substitutes. Present day chemists still prepare diverse Schiff base ligands referred to as "fortunate ligands" Cozzi, 2004). Schiff base ligands and their metal complexes have been established as biochemically active chemotherapeutic agents with antibacterial, antifungal, anticancer, antioxidant, anti-inflammatory, antimalarial, antiviral activities and also as catalyst in several reactions such as polymerization reaction, reduction of thionyl chloride, oxidation of organic compounds, etc (Lashanizadegan and Jamshidbeigi, 2011). Presence of aryl substituents usually eases the synthesis and stability of Schiff bases while those containing alkyl are relatively unstable. The reactivity of aldehydes are generally faster than those of ketones in condensation reaction, thereby resulting in the formation of Schiff bases with a centre that are less steric, relatively unstable and freely polymerizable. Schiff bases of aliphatic aldehydes are relatively unstable and are readily polymerizable while those of aromatic aldehydes, having an effective conjugation system, are more stable (Hine and Yeh, 1967). Considerable attention is given to the study of Schiff bases with functionalization and modification in the chemical structure of the compound to improve its chemotherapeutic properties.<smiles>[R]NC([R2])=O</smiles>

$1^{\mathrm{o}}$ Amine $\quad$ Aldehyde or Ketone

Schiff base

water 
Metal complexes of Schiff bases as model of bioactive compounds

Transition metals have initiated the development of metal based drugs with promising pharmacological application and may offer unique therapeutic opportunities. Research has shown significant progress in utilization of transition metal complexes as drugs to treat several human diseases like carcinomas, lymphomas, infection control, anti-inflammatory and neurological disorders (Chohan and Sheazi, 1999).

The recognition of Schiff base complexes as models for biologically active compounds has brought rapid advancement within the field of coordination and bio-inorganic chemistry and spawned extensive research on their synthesis and applications (Chohan and Sheazi, 1999). Schiff's bases and their complexes continue to attract many researchers because of their wide applications in food industry, dye industry, analytical chemistry, catalysis and pharmacological application like antitumor, antifungal, antibacterial (Ashraf et al,. 2011, Brodowska et al,. 2014). It has been confirmed that some Schiff bases show increased bioactivity when given out as metal complexes (ElSherifet al,.2012) and a number of metal chelates with anticancer activity have also been reported (Dwyer et al,. 1965).

Aims and objectives

This research is aimed at the synthesis and characterization of ruthenium (II)complexes derived from $\left[\mathrm{Ru}(\text { phen })_{2} \mathrm{Cl}_{2}\right] \cdot 2 \mathrm{H}_{2} \mathrm{O}$ and $\left[\mathrm{Ru}(\mathrm{bpy}){ }_{2} \mathrm{Cl}_{2}\right] \cdot 2 \mathrm{H}_{2} \mathrm{O}$ and to evaluate their antibacterial and antifungal activities. The proposed targets may result in the development of a drug with increased cytotoxicity compared to commercially available drugs.

\section{Experimental}

Materials and Methods

All chemicals were obtained from Sigma-Aldrich and used without purification. Tetrabutyl ammonium chloride (TBACl) and palladium on activated charcoal $10 \% \mathrm{Pd} / \mathrm{C}$ were purchased from E. Merck (India).All the reactions were monitored by checking TLC of the reaction mixture. The complexes were purified by column chromatography. The ligand and the complexes were characterized by standard analytical techniques (FT-IR, Mass, UV-visible spectroscopy and Elemental analysis).

Preparation of the starting materials

The following precursor molecules that are necessary for the synthesis of new ligand investigated in this study have been prepared by adopting the published procedures.

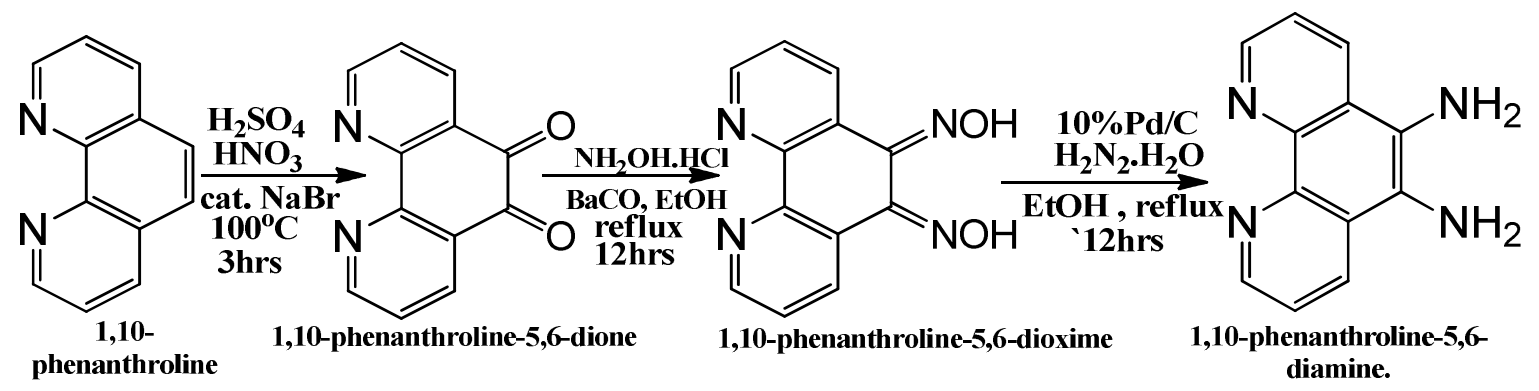

Scheme 1: Synthesis of 5,6-diamino-1,10-phenanthroline. Yamada et al,.(1992), Bodige and MacDonnell (1997)

Synthesis of 4,4-((1E,1E)-((1,10-

phenanthroline-5,6-

diyl)azanyllyllidene))bis(methanyl

lylidene))dibenzaldehyde Schiff base ligand (PDB)

The Schiff base (PDB) was synthesized by adding Benzene-1,4-dicarbaldenhyde $(0.89 \mathrm{~g}$, $2 \mathrm{mmol}$ ) in $20 \mathrm{ml}$ of ethanol to ethanolic solution of 5,6-diamino-1,10-phenanthroline

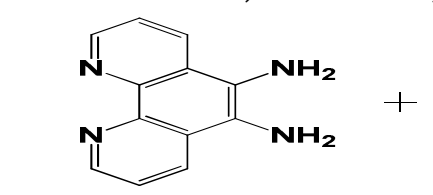

1,10-phenanthroline-5,6-diamine
$(0.21 \mathrm{~g}, 1 \mathrm{mmol})$. The mixture was refluxed for 3hours. Then solution of the ligand was kept for slow evaporation and coloured precipitate was collected and dried over $\mathrm{CaCl}_{2}$ for 2days in a desiccator. Yield: (78\%). Anal. Calc. for $\mathrm{C}_{28} \mathrm{H}_{18} \mathrm{~N}_{4} \mathrm{O}_{2}$ : C, 76.02; $\mathrm{H}, 4.07 ; \mathrm{N}, 12.67$. Found: C, 76.10; H, 4.04; N, 12.46; FAB-MS (m/z): 443 $(\mathrm{M})^{+}$; UV-Vis., $(\mathrm{nm}) ;\left(\mathrm{CH}_{3} \mathrm{CN}+\mathrm{MeOH}(9: 1): 246\right.$, 276, 390.

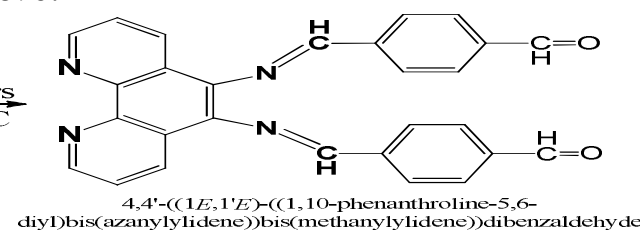

Scheme 2: Synthesis of Schiff base 
Special Conference Edition, November, 2017 Synthesis of Precursor Complexes

The following precursor complexes that are necessary for the synthesis of new complexes in this study have been prepared by adopting the published procedures.

$\mathbf{R u C l}_{3} \cdot \mathbf{3 H} \mathrm{H}_{2} \mathrm{O}+2$

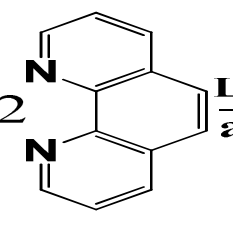

LiCl, DMF, 8hrs

phen
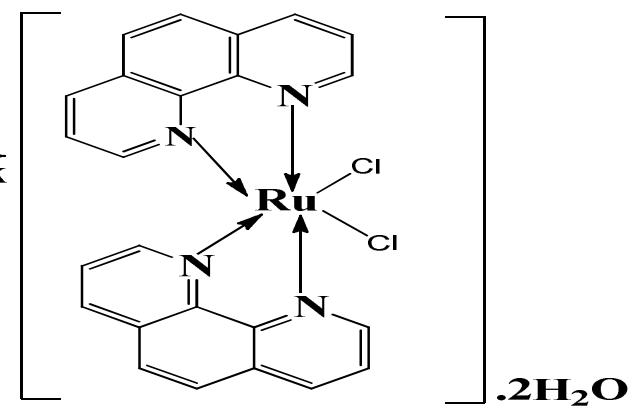

Scheme 3: Synthesis of [Ru(phen) $\left.{ }_{2} \mathrm{Cl}_{2}\right] \cdot 2 \mathrm{H}_{2} \mathrm{O}$ Sullivan and Salmon (1978)

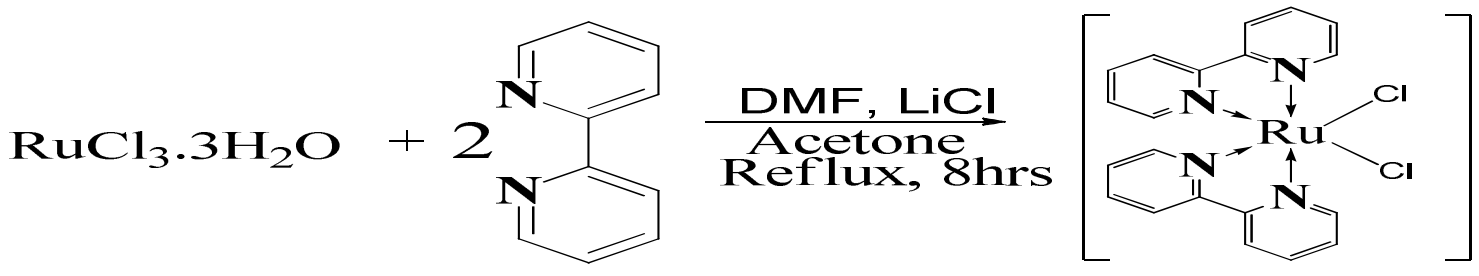

Scheme 4: Synthesis of $\left[\mathrm{Ru}(\mathrm{bpy}){ }_{2} \mathrm{Cl}_{2}\right]$ Sullivan and Salmon (1978)

Synthesis of bis(1,10-

phenanthroline)(PDB)ruthenium(II)

hexaflurophosphate, $\left[\mathrm{Ru}(\mathrm{Phen})_{2}(\mathrm{PDB})\right]\left(\mathrm{PF}_{6}\right)_{2}$

The complex was synthesized by refluxing $\mathrm{PDB}$

$(0.44 \mathrm{~g}, 1 \mathrm{mmol})$ with $\left[\mathrm{Ru}(\text { phen })_{2} \mathrm{Cl}_{2}\right] \cdot 2 \mathrm{H}_{2} \mathrm{O}$ $(0.97 \mathrm{~g}, 1 \mathrm{mmol})$ in $\mathrm{C}_{2} \mathrm{H}_{5} \mathrm{OH}-\mathrm{H}_{2} \mathrm{O}(2: 1, \mathrm{v} / \mathrm{v}$; $225 \mathrm{~mL}$ ) mixture for $5 \mathrm{hrs}$. The reddish-brown coloured crude complex was obtained on adding saturated solution of $\mathrm{NH}_{4} \mathrm{PF}_{6}$. It was purified by column chromatography (alumina, $\mathrm{CH}_{3} \mathrm{CN}$ - Toluene (3:2, v/v) mixture) and was further recrystallized from acetone-ether mixture $(1: 5, v / v)$. Yield $=0.67 \mathrm{~g}(75 \%)$. The chloride salt of $\left[\mathrm{Ru}(\mathrm{phen})_{2}(\mathrm{ptz})\right]^{2+}$ was obtained by dissolving the above hexafluorophosphate complex in minimum amount of acetone and by precipitating upon addition of a saturated solution of TBACl in acetone. Analytical data: Yield: (75\%). Anal. Calc. for $\mathrm{C}_{52} \mathrm{H}_{34} \mathrm{~N}_{8} \mathrm{O}_{2} \mathrm{RuCl}_{2}$ : C, 64.06; H, 3.49; N, 11.50. Found: $\mathrm{C}, 64.01 ; \mathrm{H}$, 3.42; $\mathrm{N}, 11.00$. MS (FAB) $\mathrm{m} / \mathrm{z}$ Calc. $[\mathrm{M}]^{+}$, 974.07; Found: $[\mathrm{M}]^{+}$, 974.75.UV-Vis: $\left(\mathrm{CH}_{3} \mathrm{CN}\right.$, $n m): 225,265,449$.

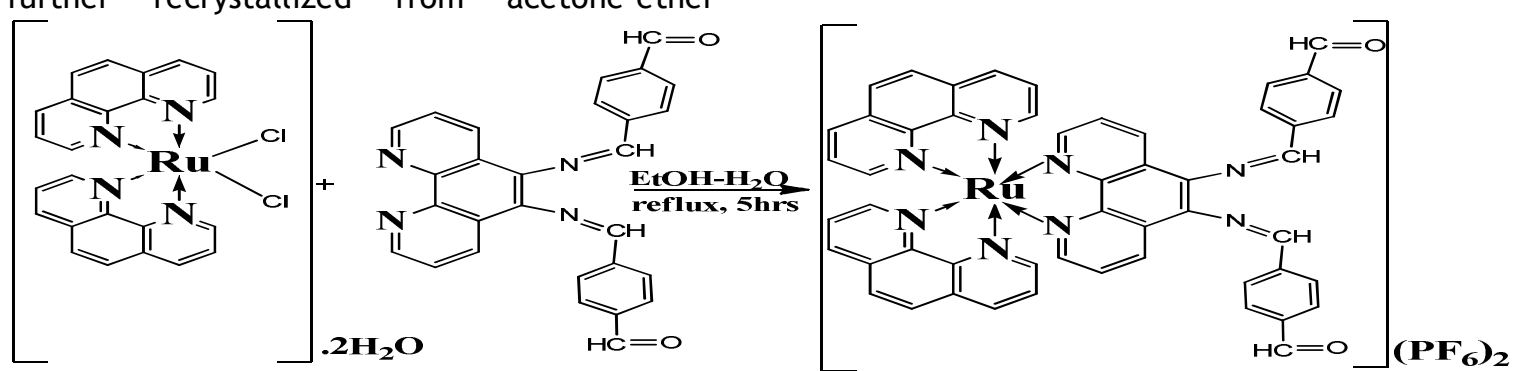

Scheme 5: Synthesis of $\left[R u(p h e n)_{2}(P D B)\right]\left(P F_{6}\right)_{2}$

Synthesis of bis(2,2-

bipyridine)(PDB)ruthenium(II)

hexaflurophosphate, $\left[\mathrm{Ru}(\mathrm{bpy})_{2}(\mathrm{PDB})\right]\left(\mathrm{PF}_{6}\right)_{2}$

This complex was synthesized by refluxing PDB $(0.44 \mathrm{~g}, 1 \mathrm{mmol})$ with $\left[\mathrm{Ru}(\mathrm{bpy})_{2} \mathrm{Cl}_{2}\right] . \quad(0.93 \mathrm{~g}$, $1 \mathrm{mmol})$ in $\mathrm{C}_{2} \mathrm{H}_{5} \mathrm{OH}-\mathrm{H}_{2} \mathrm{O}(2: 1, \mathrm{v} / \mathrm{v} ; 225 \mathrm{~mL})$ mixture for 5 hrs. The orange-brown crude complex was obtained on adding saturated solution of $\mathrm{NH}_{4} \mathrm{PF}_{6}$. It was purified by column chromatography (alumina, $\mathrm{CH}_{3} \mathrm{CN}$ - Toluene $(3: 2, \quad v / v)$ mixture) and was further recrystallized from acetone-ether mixture $(1: 5$, $\mathrm{v} / \mathrm{v})$. Yield $=0.58 \mathrm{~g}(76 \%)$. The chloride salt of $\left[\mathrm{Ru}(\text { phen })_{2}(\mathrm{pdb})\right]^{2+}$ was obtained by dissolving the above hexafluorophosphate complex in minimum amount of acetone and by precipitating upon addition of a saturated solution of TBACl in acetone.

Analytical data: Yield: (76\%). Anal. Calc. for $\mathrm{C}_{48} \mathrm{H}_{24} \mathrm{~N}_{8} \mathrm{O}_{2} \mathrm{RuCl}_{2}$ : C, 62.20; H, 2.59; N, 12.09 . Found: C, 61.81; H, 5.42; N, 12.07. MS (FAB) $\mathrm{m} / \mathrm{z}$ Calc. $[\mathrm{M}]^{+}$, 926; Found: $[\mathrm{M}]^{+}$, 925.70.UVVis: $\left(\mathrm{CH}_{3} \mathrm{CN}, \mathrm{nm}\right): 219,288,352$, and 449. 
Special Conference Edition, November, 2017

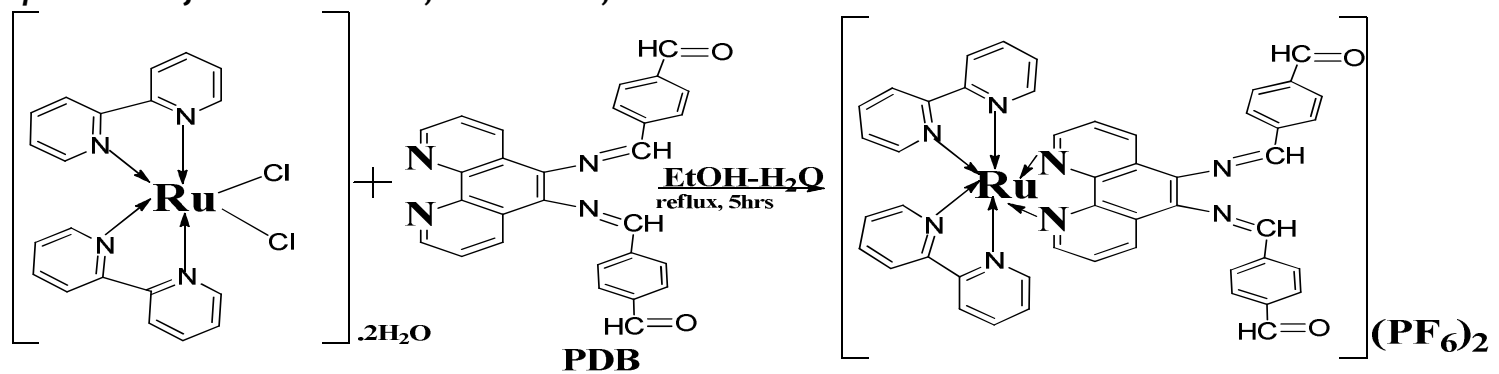

Scheme 6: Synthesis of $\left[\mathrm{Ru}(\mathrm{bpy})_{2}(\mathrm{PDB})\right]\left(\mathrm{PF}_{6}\right)_{2}$

Molar Conductivity Measurements

The molar conductance values of the complexes measured at room temperature in DMF solution with $0.001 \mathrm{M}$ concentration fall in the range 82 $89 \mathrm{ohm}^{-1} . \mathrm{cm}^{2} \mathrm{~mol}^{-1}$ indicating the electrolytic nature of the complexes, due to presence of chloride ions as a counter ions thus supports the $\left[\mathrm{Ru}(\text { phen })_{2} \mathrm{PDB}\right] \mathrm{Cl}_{2}$ and $\left[\mathrm{Ru}(\mathrm{bpy})_{2} \mathrm{PDB}\right] \mathrm{Cl}_{2}$ formulae. The nature of complexes solutions is electrolytic in 1:2 ratios due to presence of chloride ions in the outer sphere of complexes Antimicrobial activity

The Schiff base and its Ru(II) complexes were evaluated for antimicrobial activity by agar well diffusion method against the bacteria Salmonella typhi, Pseudomonas aeruginosa, Escherichia coli and Staphylococcus aureus and antifungal activities against the fungi Aspergillus niger, Aspergillus flavus nd Rhizoctoni abataicola cultured on potato dextrose agar as medium. The stock solution was prepared by dissolving the compounds in DMSO. The antimicrobial activities were performed in triplicate using $30 \mu \mathrm{gml}^{-}$ ${ }^{1}$ concentration of the Schiff base and the complexes. The average was taken as the final reading. The well was made on the agar medium inoculated with microorganisms and filled with the test solution. The plate was incubated for $24 \mathrm{hrs}$ for bacteria and $72 \mathrm{hrs}$ for fungi at $35^{\circ} \mathrm{C}$. During this period, the test solution was diffused and the growths of the inoculated microorganisms were affected. The inhibition zone was developed and it was measured in $\mathrm{mm}$. Zone of inhibition of the investigated compounds against the bacteria and fungi are summarized in Table 4 and 5 . Streptomycin and Nystatin were used as standard reference compounds for antibacterial and antifungal activities respectively.

RESULTS AND DISCUSSION

Table 1: Percentage yield and some physical properties of PDB and $\mathrm{Ru}(\mathrm{II})$ complexes

\begin{tabular}{cccc}
\hline Properties & Schiff Base & {$\left[\mathrm{Ru}(\text { phen })_{2} \mathrm{PDB}\right] \mathrm{Cl}_{2}$} & {$\left[\mathrm{Ru}(\mathrm{bpy})_{2} \mathrm{PDB}\right] \mathrm{Cl}_{2}$} \\
\hline $\begin{array}{c}\text { \% yield } \\
\text { Colour }\end{array}$ & $\begin{array}{c}78 \% \\
\text { greenish-yellow }\end{array}$ & $\begin{array}{c}75 \% \\
\text { Reddish-brown }\end{array}$ & $\begin{array}{c}76 \% \\
\text { Orange-brown }\end{array}$ \\
$\begin{array}{c}\text { Appearance } \\
\text { Melting point }\end{array}$ & Powder & Crystalline powder & Crystalline powder \\
$\begin{array}{c}\text { Decomposition } \\
\text { temperature }\end{array}$ & $>350^{\circ} \mathrm{C}$ & - & - \\
$\begin{array}{c}\text { Molar conductivity } \\
\text { Measurement }\end{array}$ & - & $240^{\circ} \mathrm{C}$ & $265^{\circ} \mathrm{C}$ \\
\end{tabular}

Molar Conductivity Measurements

The molar conductance values of the complexes measured at room temperature in DMF solution with $0.001 \mathrm{M}$ concentration fall in the range 82 -
$89 \Omega^{-1} \mathrm{~cm}^{2} \mathrm{~mol}^{-1}$. The nature of the complexes is electrolytic in $1: 2$ ratios due to the presence of chloride ions in their outer spheres. $\left[\mathrm{Ru}(\text { phen })_{2} \mathrm{PDB}\right] \mathrm{Cl}_{2}$ and $\left[\mathrm{Ru}(\mathrm{bpy}){ }_{2} \mathrm{PDB}\right] \mathrm{Cl}_{2}$ 
Special Conference Edition, November, 2017

Table 2: IR data for Schiff base and Ru(II) complexes

\begin{tabular}{lccccc}
\hline & \multicolumn{5}{c}{$\operatorname{IR} \bar{v}\left(\mathbf{c m}^{-1}\right)$} \\
\cline { 2 - 6 } Compounds & $v(\mathrm{C}=\mathrm{N})$ & $v(\mathrm{C}=\mathrm{O})$ & $v(\mathrm{C}=\mathrm{C})_{\text {aro }}$ & $v\left(\mathrm{C}-\mathrm{H}_{\text {st }}\right)_{\text {aro }}$ & $v(\mathrm{M}-\mathrm{N})$ \\
\hline PDB (Schiff base) & 1561 & 1642 & 1500 & 3080 & - \\
{$\left[\mathrm{Ru}(\text { phen) })_{2} \mathrm{PDB}\right](\mathrm{PF} 6)_{2}$} & 1550 & 1629 & 1535 & 3050 & 721 \\
{$\left[\mathrm{Ru}(\mathrm{bpy})_{2} \mathrm{PDB}\right](\mathrm{PF} 6)_{2}$} & 1549 & 1631 & 1553 & 3046 & 754 \\
\hline
\end{tabular}

The absorption bands at $1561 \mathrm{~cm}^{-1}, 1550 \mathrm{~cm}^{-1}$ and $1549 \mathrm{~cm}^{-1}$ on the spectra of PDB ligand $\left[\mathrm{Ru}(\text { phen })_{2} \mathrm{PDB}\right](\mathrm{PF} 6)_{2}$ and $\left[\mathrm{Ru}(\mathrm{bpy})_{2} \mathrm{PDB}\right](\mathrm{PF} 6)_{2}$ respectively are attributed to $\mathrm{C}=\mathrm{N}$ stretching frequencies. Similarly the absorption bands at $1642 \mathrm{~cm}^{-1}, 1629 \mathrm{~cm}^{-1}$ and $1631 \mathrm{~cm}^{-1}$ are assigned to $\mathrm{C}=0$. The absorption bands at $3080 \mathrm{~cm}^{-}$
${ }^{1} 3050 \mathrm{~cm}^{-1}$ and $3046 \mathrm{~cm}^{-1}$ in al the spectra are given to $(\mathrm{C}-\mathrm{H})$ (aromatic) stretching frequency. Whereas the new absorption bands at $721 \mathrm{~cm}^{-1}$ and $754 \mathrm{~cm}^{-1}$ in the spectra of both complexes are assigned to $\mathrm{M}-\mathrm{N}$ coordinate bonds.Arounaguiriaet al,. (2000)

Table 3:UV-Visibleand Mass spectral data for Schiff base and Ru(II) Complexes

CompoundsUV-visible $\lambda_{\max }(\mathrm{nm})(\log \varepsilon) \quad$ Mass

PDB (Schiff base)390 (3.0),246 (3.1), $276(3.3) \quad 444\left(M^{+}\right)$, base peak 222

[Ru(phen) $\left.)_{2} \mathrm{PDB}\right](\mathrm{PF} 6)_{2} 499$ (2.7), $288(3.3) 974.75(\mathrm{M})^{+}$, base-peak 341.50

$\left[\mathrm{Ru}(\mathrm{bPy})_{2} \mathrm{PDB}\right](\mathrm{PF} 6)_{2} 499(2.6), 265(3.3) 925.70(\mathrm{M})^{+}$, base-peak 299.65

${ }^{*}$ Spectra were measured in $\mathrm{CH}_{3} \mathrm{CN}$

As seen, the spectrum of PDB is characterized by low intensity, low energy absorption band due to $\pi \rightarrow \pi^{*}$ transitions at $390 \mathrm{~nm}$. This band is assigned to the azomethine chromophore attached to the phenanthroline moiety. The high-energy bands (PDB: $246 \mathrm{~nm}$ and $276 \mathrm{~nm}$ ) are attributed to the $\pi \rightarrow \pi^{*}$ transitions corresponding to the phenanthroline moiety of the ligand. The low energy band at $449 \mathrm{~nm}$ for both complexes is due to MLCT $\operatorname{Ru}(\mathrm{d} \pi)$ $\rightarrow \operatorname{PDB}\left(\pi^{*}\right)$ transition. The band centered at $265 \mathrm{~nm}$ and $288 \mathrm{~nm}$ for $\left[\mathrm{Ru}(\mathrm{bpy})_{2}(\mathrm{PDB})\right]\left(\mathrm{PF}_{6}\right)_{2}$ and
$\left[\mathrm{Ru}(\mathrm{Phen})_{2}(\mathrm{PDB})\right]\left(\mathrm{PF}_{6}\right)_{2}$ respectively are attributed to intra-ligand $\pi \rightarrow \pi^{*}$ transitions. Johnet al,..(1984).

PDB ligand mass spectrum showed base-peak at $222\left(\mathrm{M}-\mathrm{C}_{15} \mathrm{H}_{11} \mathrm{O}_{2}\right)$. In the case of corresponding mixed-ligand $\mathrm{Ru}(\mathrm{II})$ complexes the molecular ion peak for the complex $\left[\mathrm{Ru}(\mathrm{phen})_{2}(\mathrm{PDB})\right] \mathrm{Cl}_{2}$ peaks were seen at $974.75(\mathrm{M})^{+}$, The base-peak at 341.50 is for $\left(\mathrm{M}-\mathrm{C}_{7} \mathrm{H}_{4} \mathrm{O}\right)^{+}$. Similarly we also got the molecular ion peak for the complex $\left[\mathrm{Ru}(\mathrm{bpy})_{2}(\mathrm{PDB})\right](\mathrm{Cl})_{2}$ at $925.70(\mathrm{M})^{+}$.Suma et al,. (2012).

Antibacterial Activity

Table 4:Antibacterial activity of the Schiff base and its Ru(II) complexes

\begin{tabular}{|c|c|c|c|c|}
\hline \multirow[t]{2}{*}{ Compounds } & \multicolumn{4}{|c|}{ Zone of Inhibition (mm) } \\
\hline & S. typhi & S. aureus & E. coli & P. aeruginosa \\
\hline Schiff Base & 5 & 6 & 6 & 7 \\
\hline$\left[\mathrm{Ru}(\text { phen })_{2} \mathrm{PDB}\right] \mathrm{Cl}_{2}$ & 9 & 9 & 8 & 10 \\
\hline$\left[\mathrm{Ru}(\mathrm{bpy})_{2} \mathrm{PDB}\right] \mathrm{Cl}_{2}$ & 8 & 9 & 8 & 11 \\
\hline $\begin{array}{l}\text { Streptomycin } \\
\text { (Control) }\end{array}$ & 13 & 16 & 15 & 15 \\
\hline
\end{tabular}

Antifungal Activity

Table 5:Antifungal activity of the Schiff base and its Ru(II) complexes

\begin{tabular}{lccc}
\hline Compounds & \multicolumn{3}{c}{ Zone of Inhibition (mm) } \\
& Aspergillus niger & Aspergillus flavus & Rhizoctonia bataicola \\
\hline Schiff Base & 4 & 4 & 5 \\
{$\left[\right.$ Ru(phen) ${ }_{2} \mathrm{PDB}_{\mathrm{C}} \mathrm{Cl}_{2}$} & 7 & 7 & 8 \\
{$\left[\mathrm{Ru}(\mathrm{bpy})_{2} \mathrm{PDB}\right] \mathrm{Cl}_{2}$} & 7 & 7 & 9 \\
Nystatin & 11 & 10 & 13 \\
(Control) & & & \\
\hline
\end{tabular}


Special Conference Edition, November, 2017 The Schiff base and the complexes show more activity against Pseudomonas aeruginosa and Rhizoctonia bataicola. Generally, the results indicate that the complexes are more potent when compared to the ligand.

CONCLUSION

We have successfully synthesized novel Ru(II) complexes with coordinating Schiff base which was characterized by elemental analysis, FTIR, ${ }^{1} \mathrm{HNMR}$, UV-visible and mass spectral analysis. The data of molar conductivity in dimethylsulphoxide (DMSO) solutions shows the electrolytic behavior of both complexes in 1:2 ratios suggesting the presence of chloride ions in the outer sphere of complex structures.
Octahedral geometry for $\left[\mathrm{Ru}(\text { phen })_{2} \mathrm{PDB}\right] \mathrm{Cl}_{2}$ and $\left[\mathrm{Ru}(\mathrm{bpy})_{2} \mathrm{PDB}\right] \mathrm{Cl}_{2}$ were proposed according to the data obtained from molar conductivity, elemental and spectral analyses. The antimicrobial activity of the ligand and the complexes were screened against four bacteria and three fungal species and the obtained inhibition zones data indicate the possibility of their applications in the treatment of diseases. ACKNOWLEDGEMENT

We sincerely acknowledged SRM Research Institute and Faculty of Bioengineering, SRM University, Kattankulathur Campus, India for providing all the necessary facilities required for this work.

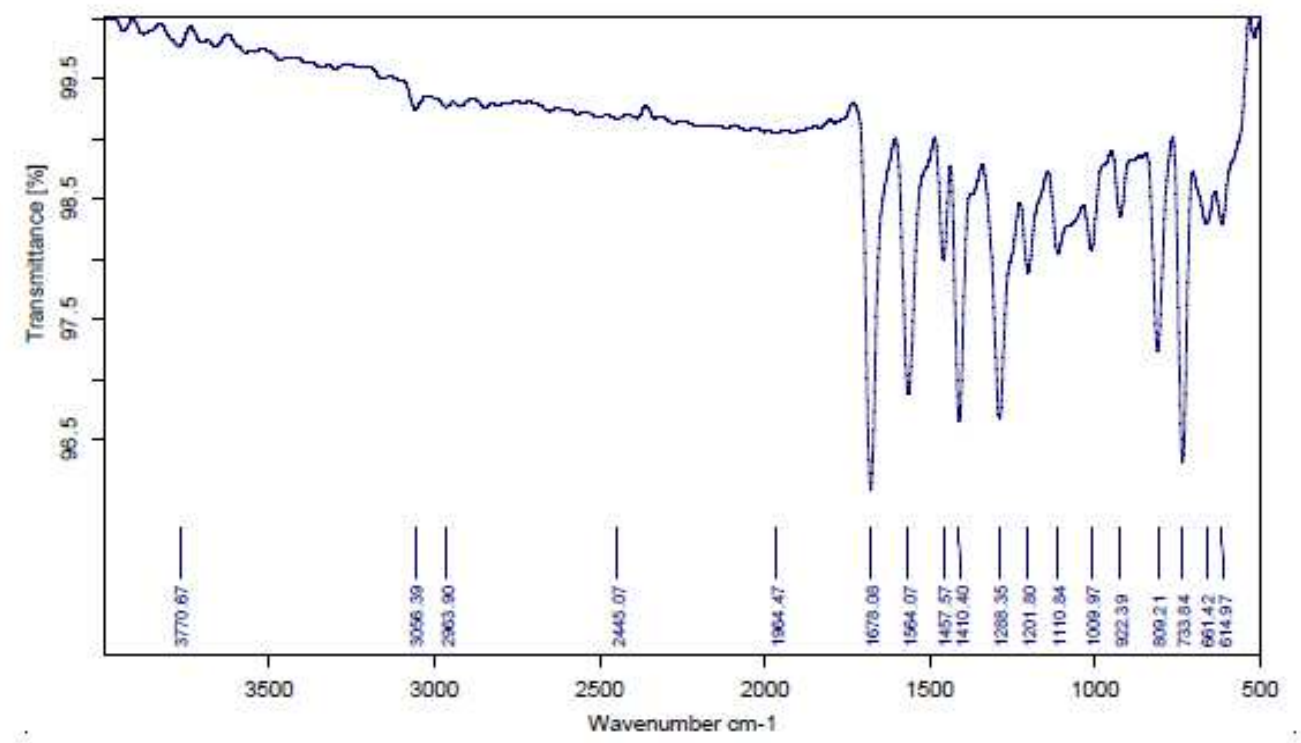

Fig. 1: IR Spectrum of PDB

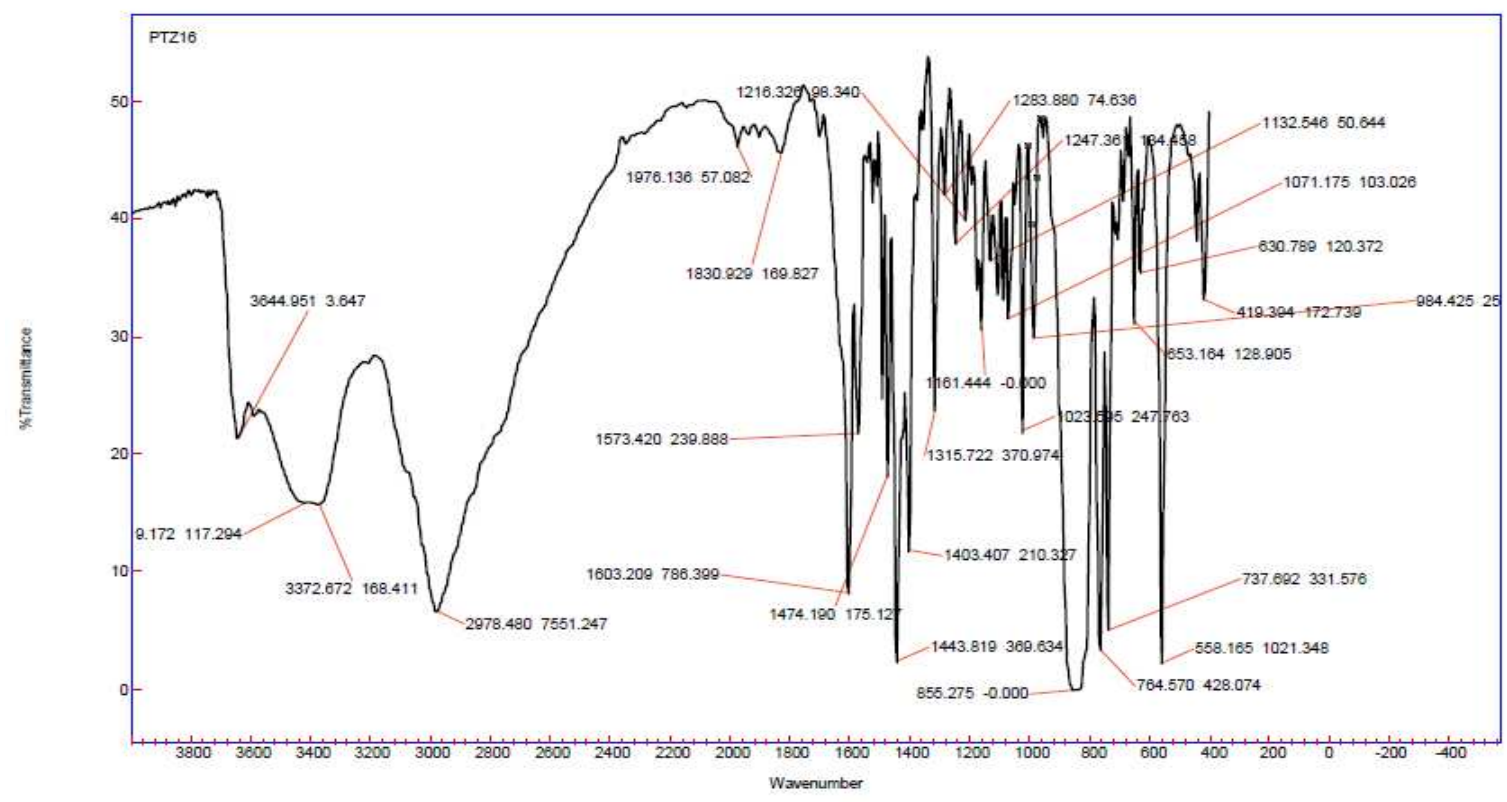

Fig. 2: IR Spectrum of $\left[R u(\text { phen })_{2} P D B\right]\left(P_{6}\right)_{2}$ 
Special Conference Edition, November, 2017

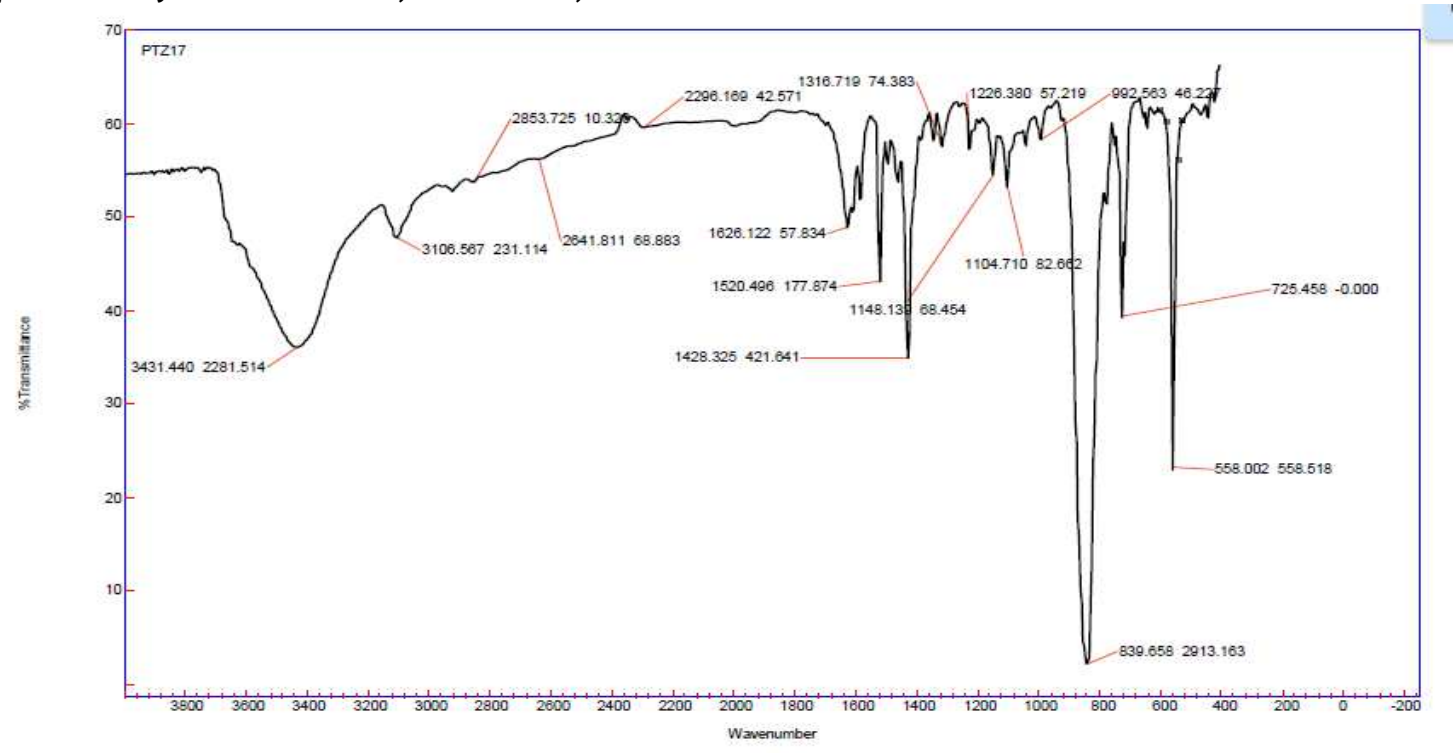

Fig. 3: IR Spectrum of $\left[\mathrm{Ru}(\mathrm{bpy})_{2} \mathrm{PDB}\right](\mathrm{PF} 6)_{2}$

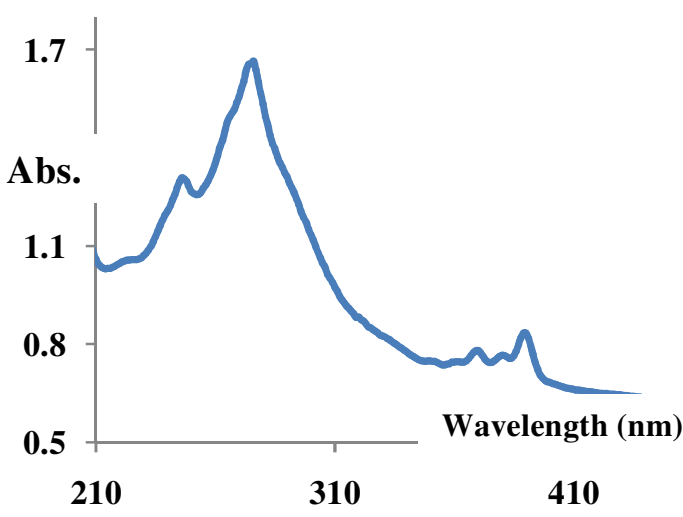

510

610

Fig.4:UV-Vis absorption spectrum of Schiff base(PDB)

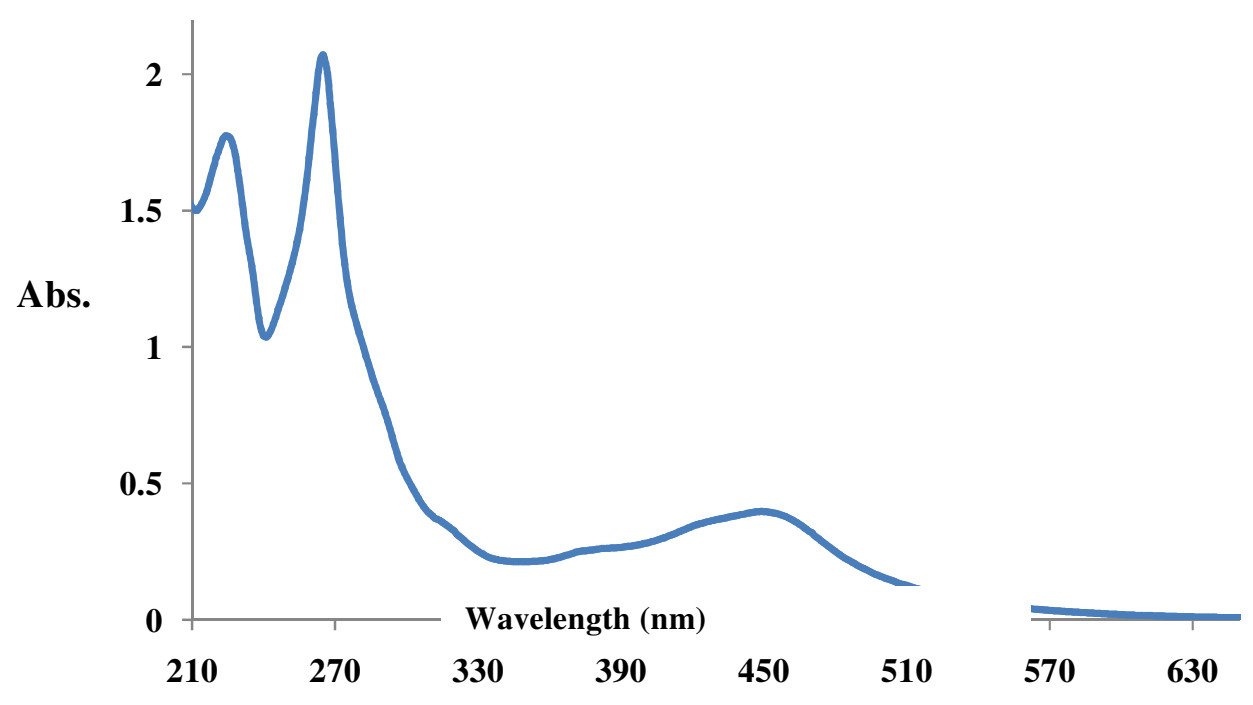

Fig.5: UV-Vis absorption spectrum of $\left[\mathrm{Ru}(\mathrm{phen})_{2}(\mathrm{PDB})\right]\left(\mathrm{PF}_{6}\right)_{2}$ 
Special Conference Edition, November, 2017

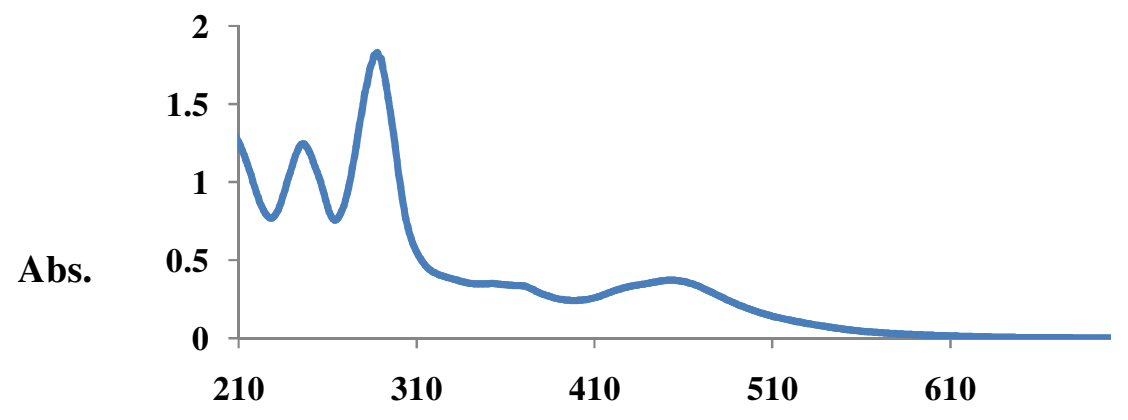

Fig.6:U' Wavelength (nm) $\left.\left.\quad \mathrm{DB}^{\mathrm{N}}\right)\right]\left(\mathrm{PF}_{6}\right)_{2}$

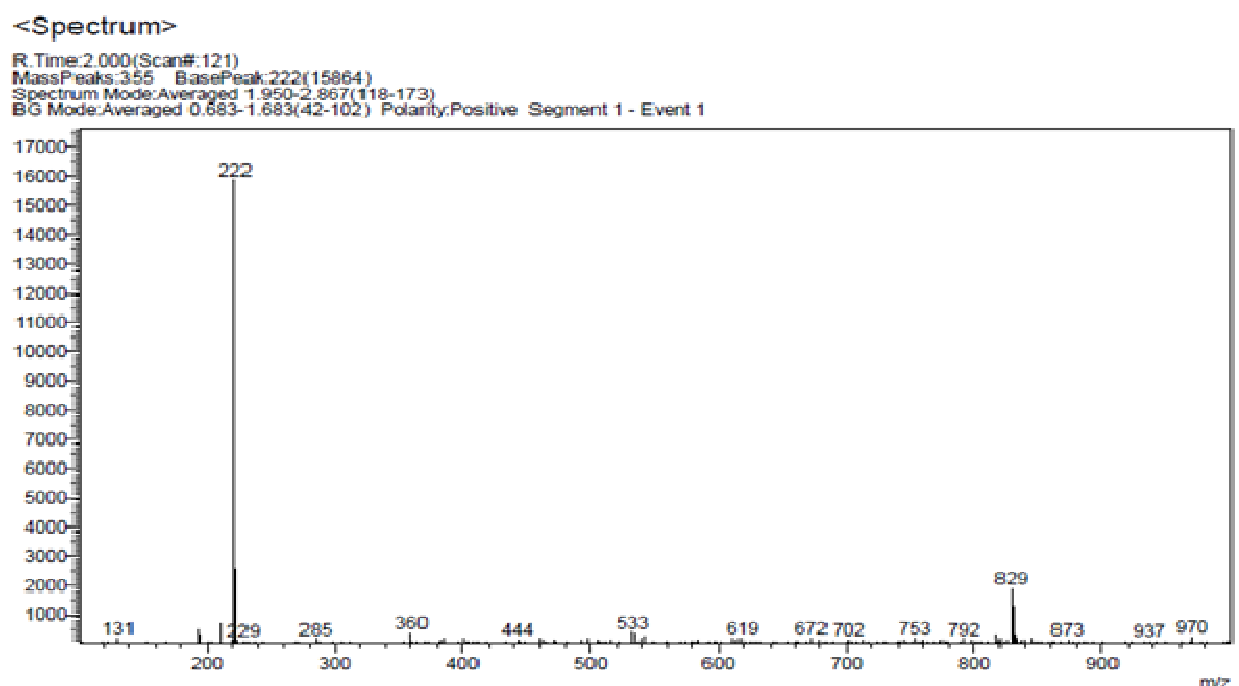

Fig.7: mass spectrum of Schiff base(PDB)

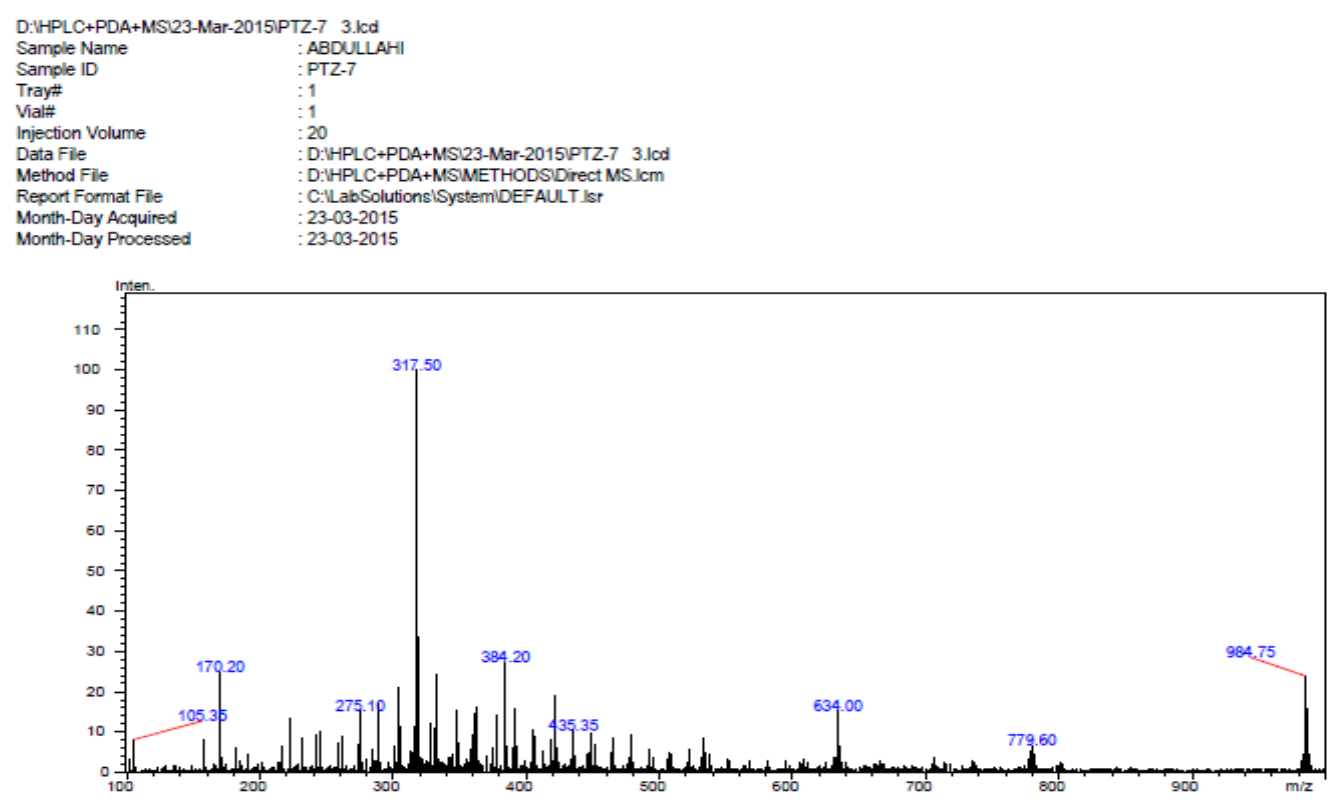

Fig.8: Mass spectrum of $\left[\mathrm{Ru}(\text { phen })_{2} \mathrm{PDB}\right] \mathrm{Cl}_{2}$ 


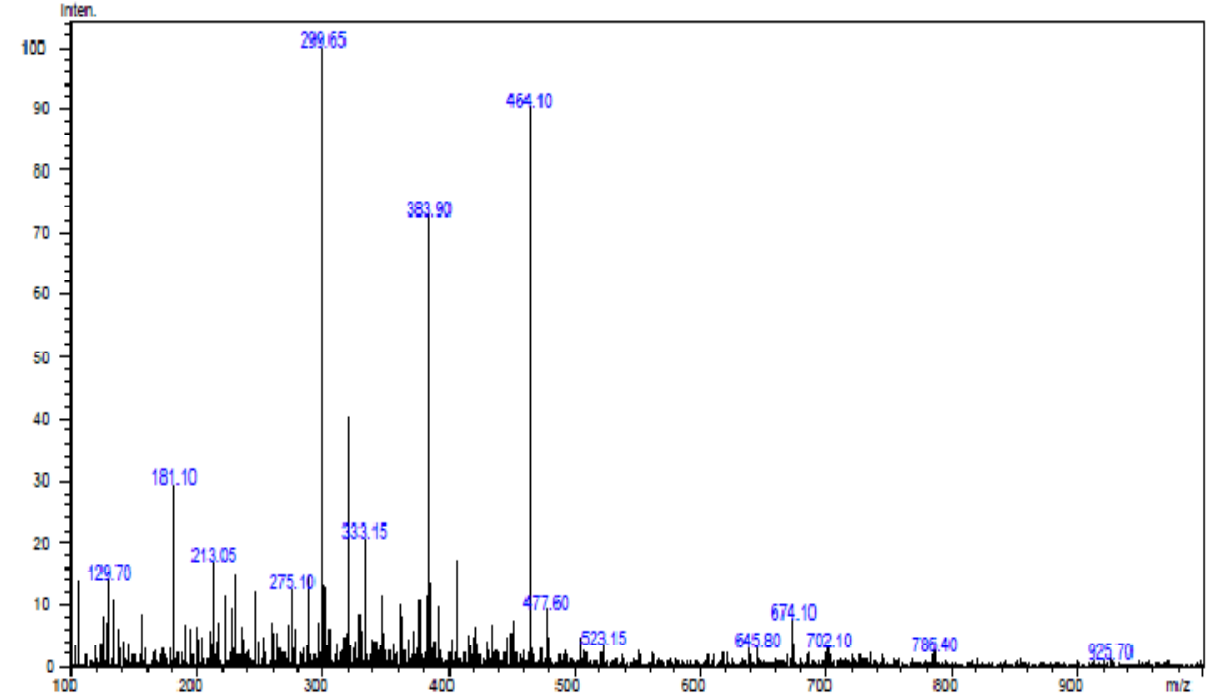

Fig. 9: Mass spectrum of $\left[\mathrm{Ru}(\mathrm{bpy})_{2} \mathrm{PDB}\right] \mathrm{Cl}_{2}$

\section{REFERENCES}

Arounaguiria, S.; Easwaramoorthya D.;Ashokkumara,

A.;AparnaDattaguptab.; and Bhaskar, G. (2000).Cobalt(III), nickel(II) and ruthenium(II) complexes of 1,10phenanthroline family of ligands, DNA binding and photocleavage studies.Indian Acad. Sci. (Chem. Sci.), 112(1), 1-17.

Ashraf, M.A.; Mahmood, K.; Wajid, A. (2011). Synthesis, characterization and biological activity of Schiff bases. IPCBEE, (185)10, 1-7.

Bodige, S.; MacDonnell, F. M. (1997)Tett.Lett, $38,8159$.

Brodowska, K.; Lodyga-Chruscinska, E.(2014).Schiff bases-interesting range of applications in various fields of science.CHEMIK 68, 129-134.

Chohan, Z.H.; Sheazi, S.A. (1999). Synthesis and characterization of some Co(II), $\mathrm{Cu}(\mathrm{II})$ and $\mathrm{Ni}(\mathrm{II})$ complexes with nicolinylhydrazine derivatives and their biological role of metals and anions $\left(\mathrm{SO}_{4}{ }^{2-}, \mathrm{NO}_{3}{ }^{-}, \mathrm{C}_{2} \mathrm{O}_{4}{ }^{2-}\right.$ and $\left.\mathrm{CH}_{3} \mathrm{CO}_{2}{ }^{-}\right)$on the antibacterial properties. Synth. React. Inorg. Met.-Org. Chem, 29, 105-118.

Cozzi, P.G. (2004). Metal-Salen Schiff base complexes in catalysis: Practical aspects. Chem. Soc. Rev, 33, 410-421.

Dwyer, F.P.; Mayhew, E.; Roe, E.M.F.; Shulman, A. (1965). Inhibition of landschutz ascites tumour growth by metal chelates derived from $3,4,7,8$ Tetramethyl-1,10-phenanthroline. $\mathrm{Br}$. J. Cancer, 19, 195-199.

El-Sherif, A.A.; Shehata, M.R.; Shoukry, M.M.; Barakat,

M.H.(2012).Synthesis, characterization, equilibrium study and biological activity of $\mathrm{Cu}(\mathrm{II}), \mathrm{Ni}(\mathrm{II})$ and Co(II) complexes of polydentate Schiff base ligand. Spectrochim. Acta Part A, 96, 889-897.

Hine, J.; Yeh, C.Y. (1967). Equilibrium in formation and conformational isomerization of imines derived from isobutyraldehyde and saturated aliphatic primary amines. J. Am. Chem. Soc. 89,2669-2675.

John, G.G.; Paul, G.B.; Kenneth, A.N.; William H.W.; and Allen, J.B.(1984).Oxidation of bipyridine and phenanthroline complexes of osmium, ruthenium and iron.Inorg. Chem,23(1), 3-10.

Kostova, I.; Sasa, L.(2013). Advances in research of Schiff-base metal complexes as potent antioxidants. Curr. Med. Chem,20, 4609-4632.

Lashanizadegan, M.; Jamshidbeigi, M.(2011). Template synthesis of un-symmetrical tetradentate Schiff base complexes of $\mathrm{Ni}(\mathrm{II}), \mathrm{Co}(\mathrm{II}), \mathrm{Zn}(\mathrm{II})$ and X-ray structure of Ni(II) complex. J. Sci. I. R. Iran, 22, 121-124.

Sullivan, B. P.; Salmon, D. J.; Meyer, T. J. (1978).Inorg.Chem, 17, 3334.

Suma, B.V.; Natesh,N.N.; Venkataramana C.H.S.; Judy, J.;Madhavan, V.(2012). Synthesis and antibacterial studies of some new 1,2,3-benzotriazoles derivatives containing pyrazolidinedione moieties. International Journal of Pharmacy and Pharmaceutical Sciences,4(1). 115-117

Yamada, M.; Tanaka, Y.; Yoshimoto, Y.; Kuroda, S.; Shimao, I.(1992).Bull. Chem Soc. Jpn, 65, 1006. 